\title{
Sustainability knowledge, attitude and practices of Malaysians
}

\author{
M. S. Aini, P. Laily, Y. Nurizan, H. Sharifah Azizah, J. Zuroni, \\ \& S. Norhasmah \\ Department of Resource Management and Consumer Studies, \\ Faculty of Human Ecology, University Putra Malaysia, \\ Malaysia
}

\begin{abstract}
Malaysia has progressed and developed at an unprecedented rate and has transformed herself from an agrarian to an industrialized nation. As a corollary to development and industrialization, the nation is facing a tremendous challenge in ensuring sustainable development as not only patterns of production but consumption and lifestyles have been transformed accordingly. A survey was conducted to gauge the level of sustainability knowledge, attitude and practices of the public officers of the nation. A total of 1246 respondents were randomly selected from nine government departments. They were $52.9 \%$ males and $47.1 \%$ females with ages ranging from 23 to 50 years old. Data indicated that the main sources of environmental knowledge were television, radio, magazines and books. The environmental knowledge of the respondents was very commendable where $70.1 \%$ of the respondents had all the answers correct. The environmental attitude of the respondents was found to be positive with a mean of 3.86 on a scale of 1 to 4 . Adoption of sustainable practices among the respondents was rather laudable with a mean of 3.44 which indicates that those activities were somewhat regularly performed. However efforts to conserve particularly water and electricity were rather dismal both in the work place and the home. Relationships between variables were also investigated. Strategies and approaches to enhance sustainable commitment and participation were discussed and proposed.
\end{abstract}

Keywords: $\quad$ sustainable practices, environmental attitude, environmental knowledge, public officers. 


\section{Introduction}

Environmental problems have been recognized and acknowledged at the United Nations Conference held in Rio de Janeiro in 1992, which culminated in Agenda 21. However a review by the United Nations Environmental Program (UNEP, [18]) asserted that the global system of environmental management is moving in the right direction but much too slowly. It is predicted that if the present trend of economic growth and consumption pattern continues, the natural environment will be increasingly stressed. Among the full scale environmental emergencies recognized by United Nations Development Program (UNDP) are water supply, land degradation, forest destruction, loss of biodiversity, urban air pollution and global warming.

Among the key environmental problems faced by Malaysia are: about $73 \%$ of Malaysian rivers are polluted (ranging from slightly to very polluted); solid waste problem with a generation rate of $1.0 \mathrm{Kg} /$ day per person but a very low recycling rate of about 5\%; air quality problem particularly in the urban areas; and an increase in the amount of toxic and hazardous waste emanated by industries (Eighth Malaysia Plan, [8]). In order to address these environmental problems, the Malaysian Government had started to integrate environmental considerations in the formulation of projects and programs since the Sixth Malaysia Plan (1991-1995). This is to ensure efficient management of the environment and its natural resources in order to attain sustainable development. Various strategies have been undertaken by the Government to address the tenets of Chapter 36 of Agenda 21, which is promoting environmental education, public awareness and training: broad base campaigns through the mass media to encourage the life-long process of environmental education; infusing formal environmental education in school curriculum; incorporate environmental education subject in teachers' training syllabus; establishment of Research Center for Environmental Health; active participation of public and private sectors including non-governmental organizations in promoting environmentally responsible practices; and developed partnership with various countries such as Denmark and Japan on capacity building, training and research in environment and environmental education (Seventh Malaysia Plan, [15]).

Malaysia, which is at an intermediary stage of development, is facing tremendous challenge in ensuring sustainable development. Since independence in 1957, Malaysia has transformed herself from an agrarian to an industrialized nation and envisaged to be a fully developed and industrialized country by the year 2020. Industrialization has induced changes not only in patterns of production but has resulted in high urbanization rate $(55.1 \%$ in 1995 to $66.9 \%$ in 2005) (Eighth Malaysia Plan, [8]) and consequently in consumption and lifestyle of the populace.

\section{Literature review}

It was found that failure to overcome environmental problems or failure to preserve a healthy environment is a result of overemphasis in technical, socio- 
economic and political factors and inadequate attention given to non-economic value of the environment (Tikka, et. al., [17]). Studies have shown that the most significant factors affecting nature is not the official government policy but public awareness (Chukwuma, [6]) or public concern for environment and the readiness to bear the cost of minimizing the adverse impacts of their activities (Ramsey and Rickson, [12]). Thus the root causes of environmental problems are related to human activities, consumption and production patterns, many of which are unaffected by environmental policies. Environmental degradation is a global concern for its effects are borderless and the quality of life of the present and of future generation depends on the protection and preservation of ecosystems.

Many studies have investigated factors related to sustainable such as behaviour, knowledge, attitude, awareness, concern, nature related activities and demographic factors. Studies by various scholars have demonstrated that the quality of the environment depends critically on the level of knowledge, attitude, values and practices of the people (Schulitz and Oskamp, [14]; Mansaray and Ajiboye, [9]). However findings on relationship between these variables have been mixed. Environmental knowledge is an important factor in consumer behaviour but the findings were shown to vary from knowledge to have significant positive relationship (Laroche et al., 2001; Bartkus et al., [4]; Vining and Ebreo, [19]) to non-significant relationship (Aini et al., [3]; Synodinos, [16]). Studies by Aini et al. [2,3] had found that Malaysian teachers and students had a fair understanding but generally poor in the identifying the underlying causes of environmental problems.

Concern for environment is a global phenomenon, emerging from multiple sources such as direct observation of environmental degradation, personal experience of its negative impacts and effects environmental education through formal or informal means. This was substantiated by an international survey by Dunlap et al. [7] which indicated that citizens of many developing countries were highly concerned with the environment. Studies by various scholars in Malaysia have generally found that the attitude towards environment or level of concern for environment of the public was high; however it was not in concert with sustainable practices (Norhasmah et al., [10]; Othman et al., [11]; and Aini et al., [3]).

Previous studies in the country have gauged environmental knowledge, attitude and practices of students, teachers and general public but none on public officers. Public officers are the backbone of Malaysian Government in ensuring that the development plans are implemented and realised. It is thus appropriate that environmental gap of the public officers with respect to attitude, knowledge, and practices are assessed. Understanding of the relationship between these variables would enable various relevant parties to develop effective policies and measures in order to enhance adoption of sustainable lifestyle of individuals and society. This research was funded by a grant from the Government of Malaysia.

\section{Methodology}

The research design was a descriptive type of study utilizing survey method. The population of the study was public officers of the Malaysian Government. 
Samples were selected from nine departments ranging from the Department of Health, Education, Environment, Transport, Agriculture, Human Resource, Finance, Statistics and Primary Industry. A total of 1246 samples were randomly selected representing officers of various ranks and categories. Data was collected in June 2005 and a response rate of $100 \%$ was achieved because the questionnaires were distributed and collected back through the assistance of the office of Heads of Departments. The instrument was in Bahasa Melayu (National language) and consisted of four main sections: demography; environmental knowledge; environmental attitude and sustainable practices. There were 22 questions on environmental knowledge encompassing fundamental concept (such as aim of sustainable development), underlying causes (e.g. sources of environmental pollution), and effect (e.g. loss of bio-diversity). The response category was yes, no or not sure of the answer. Attitude towards environmental was gauged through 11 statements, with a response format of a four- points Likert scale ranging from strongly agree (4) to strongly disagree (1). Sustainable behaviour refers to consumption practices in which a person takes into consideration the impact of his purchasing, utilization or choices of his action to the environment. It was assessed through 12 statements with a response format of 4 for all the time, 3 for always true, 2 for sometime true and 1 for never true. . Pilot study was conducted and the wording of the questionnaire was amended accordingly. The post-test value of reliability coefficient (Cronbach's Alpha) of the instrument was 0.62 for both attitude and behaviour scale. There were two open ended questions where the respondents were asked to list three sustainable practices that are most often done at the office and at home.

\section{Findings and discussion}

The respondents consisted of $52.9 \%$ males and $47.1 \%$ females. The age ranges from 23 years to maximum of 50 years, with almost $50 \%$ of the respondents were in the age group of between 23 to 35 years. As for the ethnic distribution, Malays accounted for $60.8 \%$ of the respondents while $25.3 \%, 12.4 \%$ and $1.4 \%$ were Chinese, Indians and others respectively. In terms of job categories, $48.1 \%$ of respondents were professionals, $27.4 \%$ were white collar workers (Diploma holders) and the rest (24.5) were blue collar workers. The salary of the respondents ranges from RM 500 (USD 125) to RM5560 (USD 1390) per month. This salary range reflects a typical salary scheme among Malaysian civil servants. Table 1 shows the data of some selected demographic variables.

Membership of social and environmental clubs and sources of environmental knowledge of respondents is shown in Table 2. More than 50\% of the respondents were members of Kelab Pencinta Alam (Love Nature Club) and slightly more than a quarter of them were consumer club members.

Television, radio, books and magazines were the main sources of environmental information and knowledge for almost all the respondents. This finding differs slightly from an earlier study which was conducted among households in the State of Selangor where newspaper, television and radio were 
the primary sources of environmental information (Nurizan et al., 2004). A sizeable proportion of respondents $(66.4 \%)$ stated that environmental knowledge was obtained from formal education (Table 3 ). A cross tabulation is made to compare between three different categories of educational background of the respondents (group $1=$ up to secondary education; group $2=$ college/ diploma; and group $3=$ tertiary education level i.e. Degree and postgraduates) with formal education as a source of environmental knowledge. It was found that $85.3 \%$ of those in group 3 education level stated that environmental knowledge was gained through formal education, while $47.9 \%$ and $5.9 \%$ of group 2 and 1 stated so. Similar percentage distribution was found with regards to the use of Internet as a source of environmental information. Thus formal education and Internet as sources of environmental knowledge seem to be more popular among higher educated respondents.

Table 1: $\quad$ Percentage distribution of selected demographic variables.

\begin{tabular}{|l|l|}
\hline Variables & Percentage (\%) \\
\hline $\begin{array}{l}\text { Gender } \\
\text { Male } \\
\text { Female }\end{array}$ & 52.9 \\
& 47.1 \\
\hline Age (years) & \\
$23-35$ & 50.2 \\
$36-45$ & 32.9 \\
$46-50$ & 16.9 \\
\hline Ethnic & \\
Malay & 60.8 \\
Chinese & 25.3 \\
Indians & 12.4 \\
Others & 1.5 \\
& \\
\hline Education Level & \\
Primary & 8.3 \\
Secondary & 7.4 \\
Diploma & 6.6 \\
Degree & 47.1 \\
Masters/PhD & 30.6 \\
& \\
\hline Job Category & \\
Professional/ Officers & 54.9 \\
Blue Collar (Nurses, clerks) & 42.9 \\
General workers (cleaners) & 2.2 \\
\hline & \\
\hline
\end{tabular}


Table 2: $\quad$ Percentage of Membership in social and environmental clubs.

\begin{tabular}{|l|c|}
\hline \multicolumn{1}{|c|}{ Club Membership } & Yes (Percentage) \\
\hline Love Nature Club & 53.0 \\
\hline Consumer Clubs & 26.7 \\
\hline World Wildlife Fund & 13.5 \\
\hline Welfare Club & 9.6 \\
\hline Friends of the Earth & 6.7 \\
\hline
\end{tabular}

Table 3: $\quad$ Sources of environmental knowledge.

\begin{tabular}{|l|c|}
\hline \multicolumn{1}{|c|}{ Sources } & Yes (Percentage) \\
\hline Television & 100 \\
\hline Radio & 100 \\
\hline Books & 100 \\
\hline Magazines & 99.8 \\
\hline Formal education & 66.4 \\
\hline Internet & 66.4 \\
\hline Newspaper & 16.8 \\
\hline Seminars/talks & 9.7 \\
\hline DVD & 0 \\
\hline
\end{tabular}

Environmental knowledge of the respondents was very commendable where $70.1 \%$ of the respondents had all the answers correct. Only $4.0 \%$ of the respondents scored 19 and less from a total 22 marks. Among the items that were answered wrongly or unsure were those related to the effects such as that of chemical fertilizers, pesticides, washing soap to environment. The above sources of environmental information seem to be able to impart basic environmental knowledge well but less effective on advance aspects such as the effects and impacts aspects.

Environmental attitude of the respondents was found to be positive with a mean of 3.86 on a scale of 1 to 4 . Adoption of sustainable practices among the respondents was rather commendable with a mean of 3.44 ( 1 never true to 4 all the time true) which indicates that those activities were performed rather regularly. This is somewhat promising as compared to previous studies (Aini et al., [2]; Norhasmah et al., [10]; Aini et al., [3]) where the mean score of sustainable practices was found to be below 3.0 on a similar scale. Table 4 shows the mean of each the item of sustainable practices. All the items had a score of mean above 3.0 except for two, which is with regards to trying to reduce waste production and electricity consumption.

The respondents were also asked to list three types of sustainable practices with regards to minimization of resources that they regularly undertook at the office and at home. At the office, it was found that $44.9 \%$ of respondents indicated that they tried to maximise the use of paper (using both sides of paper, reuse it) while minimization of electricity and water was mentioned by only $2.7 \%$ and $3.7 \%$ of them. As for practices at home, $13.5 \%, 6.3 \%$ and $4.5 \%$ tried to minimize the use of water, electricity and reuse of bottles consecutively. On the 
whole, the figure reflects that efforts to conserve particularly water and electricity was rather dismal both at work place and home. The findings illustrates that only a small percentage of respondents were concerned with water conservation and this corresponds with the figures whereby on average a Malaysian uses 300 Litres Per Day (LPD) of water, and urban dwellers use a lot higher at 500 LPD (Chan, [5]). This is almost doubled to that recommended amount by the United Nations which is 165 LPD. This may be due to among other factors, a relatively low water and electricity tariff in the country.

Table 4: $\quad$ Mean of items measuring sustainable practices.

\begin{tabular}{|l|l|}
\hline \multicolumn{1}{|c|}{ Item } & Mean \\
\hline Recycling household wastes & 3.74 \\
\hline Reuse of items (bottles, containers) & 3.67 \\
\hline Use both sides of papers & 3.51 \\
\hline Use own container/bags when shopping & 3.40 \\
\hline Use natural resources as insect repellent & 3.67 \\
\hline Always trying to minimize amount waste generated & 3.00 \\
\hline Purchase items wrapped/placed in reusable cases & 3.27 \\
\hline Use public transport where possible & 3.67 \\
\hline Purchase products that would last long & 3.65 \\
\hline Switch off fan or lights when unused & 3.33 \\
\hline Close the pipe when brushing teeth & 3.33 \\
\hline Reduce electricity consumption & 3.00 \\
\hline Overall mean & 3.44 \\
\hline
\end{tabular}

One-way ANOVA was tested to investigate the differences between means of three groups of educational background with three main variables of the study. Results are as displayed in Table 4. There were no significant differences in knowledge among the three groups but significant differences between groups were found for attitude and practices. Higher educated respondents had more positive attitude but it was not translated into more sustainable practices. Data indicated that although the less educated ones (group 1) had slightly lower environmental knowledge, less positive attitude towards environment but they were more involved in adoption of sustainable practices.

Table 5: $\quad$ One-way ANOVA output for attitude and sustainable practices.

\begin{tabular}{|l|lr|c|}
\hline & Education & Group & Sig. \\
\hline Attitude & & & \\
\hline & 1 & 2 & .022 \\
\hline & 1 & 3 & .001 \\
\hline Sustainable practices & & & .038 \\
\hline & 1 & 2 & \\
\hline
\end{tabular}




\section{Conclusions and implication}

Overall the findings showed that the respondents possessed good basic environmental knowledge and a positive attitude towards environment. With regards to sustainable behaviour, there is a lot of room for improvement particularly with regards to minimization of the use of water and electricity particularly at work place and waste reduction. In the wake of the recent fuel hike in the country, the Prime Minister had asserted and appealed to the civil servants to reduce consumption particularly electricity at the office and the public in general to do so. Waste reduction practices are also not encouraging although solid waste is one of major environmental problems faced by most municipalities in the country particularly in the urban areas. Mass media such as television and radio which represent main sources of environmental knowledge could be exploited by the policy makers to develop a comprehensive environmental education of the masses via this media besides enhancing it through formal environmental education at government offices. Adoption of environmentally responsible practices could further be enhanced through active participation in environmental related activities such as environmental seminars and campaigns. New approaches such as experiential learning, 'in' and 'with' nature experiences and problem-based education can further be explored.

The world is currently facing an array of planetary environmental emergencies such as pollution, environmental degradation and depletion of natural resources. As such it is pertinent that sustainable behaviors are reinforced and intensified at all levels of the society. Some environmental behaviors are matters of personnel habit and routine but some are highly constrained by other external or contextual factors such as technology, laws and regulations, social policies, social values and norms within the society. Thus it is proposed that studies are undertaken to understand those barriers that inhibit behavior change of the public so that useful and practical principles for intervention can be identified. Consequently, an integrated approach to effective formal and informal environmental education of the Malaysian society may be developed.

\section{References}

[1] Aini, M.S., Fakhru'l-Razi, A., Lau, S.M., \& Hashim, A.H., Practices, attitudes and motives for domestic waste recycling. International Journal of Sustainable Development and World Ecology, 9, pp. 232-238, 2002.

[2] Aini, M.S., Fakhru'l-Razi, A., Paim, L. \& Masud, J., Environmental concerns, knowledge and practices gap among Malaysian teachers. International Journal of Sustainability in Higher Education, 4(4), pp. 305313, 2003.

[3] Aini, M.S., Norsaadah, J. \& Siti Suhana, M.S., Understanding and participation of Malaysian youth in environment. Proceedings. $4^{\text {th }}$ KUSTEM Annual Seminar on Sustainability Science and Management, Kuala Terengganu Malaysia, 2005. 
[4] Bartkus, K.R., Hartman, C.L. \& Howell, R.D., The measurement of consumer environmental knowledge: Revisions and Extensions. Journal of Social Behavior \& Personality, 14(1), pp. 9-18, 1999.

[5] Chan, N.W., 1997/98 nationwide water crises in Malaysia: What are the real causes and lessons to be learnt? Proceedings of the International Conference on Disaster M, Lessons to be Learnt, Langkawi Malaysia, 2000.

[6] Chukwuma, C.S., Environmental issues and our chemical world- the need for a multidimensional approach in environmental safety, health and management. Environmental Management and Health, 9(3), pp. 136-143, 1998.

[7] Dunlap, R.E, Gallup, G.H \& Gallup, A.M., Results of the Health of the Planet Survey. Environment, 35(9), pp. 7-39, 1993.

[8] Eighth Malaysia Plan, Kuala Lumpur: Percetakan Nasional Malaysia Berhad, 2001.

[9] Mansaray, A. \& Abijoye, J.O., Environmental knowledge, attitudes and behaviour in Dutch Secondary School. Journal of Environmental Education, 30 (2), pp. 4-11, 1998.

[10] Norhasmah, S., Aini, M.S., Laily, P., Sharifah Azizah, H., Nurizan, Y. \& Naimah, S., Environmental attitude and practices. Malaysian Journal of Consumer and Family Economics, 7, pp.54-65, 2004.

[11] Othman, M.N., Ong, F.S. \& Lim, M.H., Environmental attitudes and knowledge of teenage consumers. Paper presented at MACFEA Seminar, Universiti Putra Malaysia, Serdang, 2003.

[12] Ramsey, C.E. \& Rickson, R.E., Environmental Knowledge and Attitudes. Journal of Environmental Education, 8, pp.10-18, 1976.

[13] Salequzzman, M. D; \& Stocker, L., The context and prospects for environmental education and environmental career in Bangladesh. International Journal of Sustainability in Higher Education, 2 (2), 104121, 2001.

[14] Schulitz, P.W., \& Oskamp, S., Effort as a moderator of the attitude behavior relationship: general environmental concern and recycling. Sociology Psychology Quarterly, 59(4), pp. 375-383, 1996.

[15] Seventh Malaysia Plan (1996). Kuala Lumpur: Percetakan Nasional Berhad.

[16] Synodinos, N.E., Environmental attitudes and knowledge. Journal of Business Research, 20: 161-170, 1990.

[17] Tikka, P. M., Kuitunen, M.T., \& Tynys, S. M., Effect of educational background on students' attitude, activity levels and knowledge concerning environment. The Journal of Environmental Education, 31(3), pp. 12-19, 2000.

[18] United Nations environment Program (UNEP), Global Environment Outlook 2000, UNEP, 1999.

[19] Vining, J. \& Ebreo, A., What makes a recycler? A comparison of recyclers and nonrecyclers. Environment \& Behavior, 22: 55-73, 1990. 